\title{
Ted Parker: a personal memoir
}

\author{
N. J. COLLAR
}

It is now two years since the death of Ted Parker, and I still find it extremely difficult to talk or write about him in the past tense. Indeed, I doubt whether anyone linked with him through ornithology or conservation has yet come to terms with the enormity of the loss. At one level, it is simply that he knew so much of Neotropical birds and their habitats, in so much depth and so much breadth: no-one was his match, and no-one expected ever to be so. At another, it is simply that he was so distinct and vivid a personality, much more than merely "charismatic": superhumanly energetic, trenchantly assertive, irrepressibly good-natured, subversively frank; and always, inexhaustibly, himself. This mix of features made him larger than life - legendary, even - and awesomely enriching to know, even to someone such as myself who, although corresponding with him for years, met him only twice.

Parker the legend first made a mark on me in 1986, at the time of an extensive mail-out to over 400 people in the New World to obtain their help with the preparation of Threatened birds of the Americas. In the responses that came back, and in the meetings and conversations that I began to have with fieldworkers throughout the region, one name came up, time and time again. "If you want to know about this one, Ted Parker's the man to ask. . ."; "I don't know anyone who's been in the area, except Ted Parker of course. . ."; "I think it's a rare bird, but you'd better check with Ted Parker. . ."

I had in fact already checked with Ted Parker, just prior to this mail-out, at least over some of the species listed in it. This is how he began his lengthy reponse (2 March 1986):

Let me say immediately that I will wholeheartedly support your effort to produce a volume on threatened birds of the New World. Indeed, I truly wish that I could devote all of my time to projects such as this, but at present I am forced to support myself by leading natural history tours, leaving little time to pursue my research interests. I would love to have a full-time position with one of the international conservation organizations (ICBP would be my first choice) and think my 15 years of fieldwork in the Neotropics would qualify me for such work. I feel that faunal (and floral) surveys are desperately needed in many parts of Central and South America, and it is unfortunate that there is such an uncoordinated effort (among the leading organizations) to set research priorities and carry out land acquisition. I am constantly being bombarded with questions from representatives of the different organizations, and it has become increasingly clear that we are all operating on different 
wavelengths. We very much need to have a conference on threatened habitats of the Neotropics, and everyone with extensive field experience should be invited to attend (not just the upper echelon people - very often those who have political connections or a certain social status) and offer their opinions regarding what needs to be done and where. How can it be that ICBP, World Wildlife Fund, and Nature Conservancy (International) employ no full-time fieldworkers in South America? (That is, people who have the necessary experience to survey vertebrates through mist-netting, trapping, tracking, tape-recording etc.). This work is highly specialized and thoroughly essential to a successful conservation effort. Are we to buy tracts of forest only to learn later that some of these are lacking many of the species they were meant to preserve? Hopefully this has not happened to date, but clearly we need a more unified and professional effort.

Please excuse this little tirade (especially in my first letter to you). I'm just becoming frustrated at not being able to contribute all of my energies to this kind of work.

Looking back on this now, one recognizes so much: the dominant passion for conservation (not just for birds); the fully formed RAP dream (it was an abiding disappointment to me that, other than in his co-authorship of the Red Data Book, ICBP was unable to repay the compliment and take advantage of his invitation); the sense of his own pioneering importance (which was never self-importance); the garrulousness; the egalitarianism; the championing of fieldwork and fieldworkers; the insistence on high standards, and impatience with the haphazard and unprofessional; exasperation over the size of his daily mail-bag; exhaustion from his overweaning schedules.

Part of his god-like status, I now suspect, stemmed from the fact that most of the time no-one knew where he was; and part of it stemmed from the fact that he was - or at least he had been - almost everywhere. He seemed for ever to be away, and this constant exposure and experience, multiplied by his phenomenal field skills, put him in a class entirely on his own. At "Workshop '90", a conference held in Manaus to map key areas of biological importance in the Amazon basin (and the occasion of our first encounter), he was certainly the outstanding figure, simply because he had been to so many of the places in question. In an article written soon after, having proposed Jürgen Haffer as the intellectual grandfather of the event, I called Ted "the meeting's favourite son... [for having] contributed more in terms of both science and plain information than any other individual in the entire gathering".

He was compulsively generous with his data, as dozens of authors bear witness (consider the extensive contributions he made to books like David Snow's Cotingas and the Islers' Tanagers). He was justly renowned for this selflessness, but it drove him eventually to live in fear of the telephone, so that he rarely gave out his number and often (so far as I could make out) changed it in order to thwart the attention of seemingly thousands of birdwatchers who wanted his advice. Contacting him during the last year of writing Threatened birds of the Americas became a nightmare, especially when it turned out that even his paymasters, Conservation International, commonly had no idea where he was. Such defiance had its risks, of course, especially given that $\mathrm{CI}$ benefits from the 
support of various very popular, high-profile sympathizers. One day the phone rang and Ted heard a voice say:

VOICE: Hi, is that Ted Parker?

PARKER: Yes it is. Who's this calling?

VOICE: This is Harrison Ford.

PARKER (in a defensive growl): Do I know you?

VOICE: Uh, well, I'm an actor. I'm on the Board of CI.

PARKER (to himself, while imploding): !?*\&\%\#@*\$!

Ted loved telling this story, rounding it off with that sharp, slow, falsetto hú-hú$h u$ with which he usually expressed his glee.

He loved telling all his stories, which his eternal travels had loaded him with, and which would pack in tighter as the evening mellowed. Most of them ended in laughter: the speed of the exit of some man picking a fight with him in a bar when his friends Steve Hilty and Mark Robbins stood up and showed their size; the speed of the exit of a jaguar coming towards him down a track in Manu, when the only thing he could think to do varas leap in the air and scream at it; the speed of the exit of some colleagues eating their lunch when he casually pointed out that the bird singing across the clearing for the past ten minutes was one of the rarer and more exquisite tanagers ("Boy, you should have seen that guy/that thing/those people move!").

Later still, and the conversation would swerve dizzyingly between various favourite topics: the ethics of collecting, the conservation shortcomings of successive U.S. administrations, the need to support young conservationists in Latin America, Bob Dylan's lyrics, Melbourne Carriker's life, and always back to birds. His love of birds and nature was at the heart of him. After he died, one of his teachers told how one day he had simply stood up and walked out of class without a word, but came back to her next day to apologize quietly and explain that the birds singing outside had made it impossible for him to sit in school any longer. I find this story particularly moving, as it holds the quintessence of Ted Parker: a man utterly true to his own internal promptings, yet also deeply respectful of other people's feelings and needs, and forever caught in the currents shifting between the two.

At Russ Mittermeier's behest Ted came over to England - his first and only visit to Europe - in late November and early December 1991 for two weeks to work at the BirdLife Secretariat on Threatened birds of the Americas. He arrived with a certain scepticism about what a Cambridge-based conservation organization could do to clarify the situation in the New World, and about British ornithologists in South America, but after only two days he had been a muchtoasted dinner guest of the Cambridge Student Birders (motto: veni, vidi, ticki) and had made firm friends with the research staff at the Secretariat ("Where do you find these guys?" he asked). He marvelled at the energy and commitment of both students and staff, but he thought rather less of the food that fuelled us and the prices we had to pay for it. In self-mocking tones he would call off an intense bout of work and declare: "I'm hungry! I'm an American!" and insist on going out for a hamburger. He drank Coca-Cola with a vengeance. I made a pyramid of his empty cans, called it the Parker memorial, and kept it in my 
office in affectionate token of his visit. Now of course I can't bring myself to throw them away.

One highlight was when Paul Salaman, who had told him about an unidentified bird from Colombia that most seemed to resemble a vireo, turned up at the Secretariat with a large colour photograph of the bird in the hand. Ted had been sceptical that this could be anything new, confidently anticipating an immature-plumaged specimen of something he could quickly identify. Several of us gathered round in silence to hear his verdict. He stared at the picture long and hard: "What the - is that?" he said. We waited while he ran a programme in his brain. For a moment he seemed to have cracked it: "Oh okay, hold on. It's. ." Another long pause: and then, with exactly the same tone and emphasis as before: "What the - is that?" Parker stuck for an identification! This was the moment we seriously started to think Paul had a sp. nov. to his credit.

In this issue of Bird Conservation International, friends, acquaintances and admirers of Ted Parker pay their respects to a master who cared as deeply as it is possible to do for the preservation of wildlife and wilderness on this planet. Another, larger volume is shortly to appear as an AOU Ornithological Monograph, where the themes range well beyond conservation. It is some measure of the man that he should be saluted twice in this fashion, but we all know why. He was a wonder. He just shone. And in the memories of those who knew him and loved him, he shines on. 